\title{
„НЕСВЯТЫЕ СВЯТЫЕ” В РАССКАЗАХ О. ЯРОСЛАВА ШИПОВА (К ВОПРОСУ ОБ ОСОБЕННОСТЯХ АВТОРСКОГО ПОЧЕРКА)
}

\author{
“THE UNHOLY SAINTS" IN THE STORIES OF FATHER YAROSLAV SHIPOV \\ (ON THE QUESTION OF THE SPECIAL FEATURES \\ OF THE AUTHOR'S STYLE)
}

\author{
СНЕЖАНА КРЫЛОВА
}

\begin{abstract}
AвSTRACT. The article analyses the originality of the narrative manner of the contemporary writer Yaroslav Shipov, in whose texts the ideals and spiritual challenge of the heroes and storyteller are always accompanied by a dense network of humor and common nonsense. Conclusions are drawn regarding the reasons for such a strategy. The prose by Shipov, though aimed at finding God's presence in the world, is stylistically and problematically associated with secular and social literature. It motivates the reader to do self-meditation and intellectual work based on the influence of suggestion.
\end{abstract}

Keywords: phenomenon of holiness, poetics of titles, intonation variability, suggestive influence

Снежана Крылова, Московский государственный областной университет, Москва Россия, sv.krylova@mgou.ru

ORCID ID: 0000-0002-4071-2884

„Несвятые святые” - универсальная формула, придуманная архимандритом Тихоном Шевкуновым в его мемуарной книге о подвижниках Псково-Печерского монастыря [Шевкунов 2011]. Универсальна она потому, что делает понятным переживание каждого человека при встрече с явлением святости. Действительно, феномен праведничества при личном, так сказать, знакомстве с праведником всегда поражает своей простотой и неканоничностью. Одно дело читать жития, другое - общаться с человеком, всем сердцем принявшим Христово учение.

Это хорошо понимает и современный писатель, мастер малой формы, священник Ярослав Шипов. Он почти неизвестен польскому читателю, зато любим христиански ориентированной публикой в России. Родился будущий отец Ярослав в Москве, в 1947 году, в семье журналистов-фронтовиков (в прошлом - сотрудников журнала „Безбожник”!), закончил Литинститут, работал в московских редакциях и „толстых” журналах, в 1980-е годы издал три книги прозы. В 40 лет он принял крещение, а в 44, 
неожиданно для себя, по настоянию прихожан восстанавливаемого им прихода в Вологодской области, стал священником. Четыре года прослужил на Вологодчине, где священников не было около 60 лет, затем вернулся в Москву, где ныне служит в одном из храмов на Варварке. Параллельно с духовным переворотом произошло и второе рождение писателя. Его первые сборники рассказов, написанные в иерейском чине, - Oтказываться не вправе (1999), Долгота дней (2002) - были неоднократно переизданы и широко разошлись по стране. Позже к ним добавились Райские хутора (2007), Лесная пустынь (2009), Первая молитва (2010, 2011).

В зрелой прозе о. Ярослава, горькой в содержательно-тематическом плане, но изящной и остроумной по манере письма, есть несколько постоянных тем: тема крушения великой державы, боли за развалившуюся страну, тема войны и её героев, тема национального одичания. Как видим, вопросы автор затрагивает печальные. И всё-таки от каждого сборника о. Ярослава идёт незримый свет. Думается, во многом он исходит от праведников, которых автор таковыми никогда не называет, но неизменно включает в свою портретную галерею - нередко в её второй или третий ряд. Пожалуй, принципы характеростроения в рассказах Шипова особенно ярко отражают своеобразие его авторского почерка. Это понятие является синонимичным авторскому стилю: „эстетической общности всех сторон и элементов произведения, обладающей определённой оригинальностью" [Гаспаров 2013: 1031].

Шиповские герои обладают типичными чертами праведников: скромностью, нестяжательностью, любовью к ближним и т.п. Но так как автор пишет не жития, а художественную прозу, то и способы выявления святости у него немного другие - прикровенные. Это идёт от особого рода целомудрия. О чём-то высоком или героическом автор всегда говорит полушуткой. Как верно подметила София Червоненко,

о. Ярослав Шипов как художник не может остаться в жёстких рамках дидактического жанра проповеди, он часто глубокие богословские вопросы помещает как бы за границами повествования, доверяя читателю, который сам разгадает глубокий смысл запечатлённых сцен и эпизодов. Нравоучительность содержания мастерски скрыта за своеобразием индивидуального стиля, речевыми характеристиками, юмором, пейзажными зарисовками [Червоненко 2012: 143].

Например, в рассказе Боковое зрение повествуется о приезде благочинного (помощника епископа, надзирающего над духовенством в церковном округе), отца Александра, в бедный, угасающий приход отца Сергия. Дело происходит на престольный праздник Георгия Победоносца, и все события даются нам в основном через размышления о. Александра и авторский скупой комментарий. 
Рассказ посвящён проблеме вымирания провинции. Церковь находится в пятидесяти километрах от города. Однако прихожан, как с тревогой замечает отец Александр, с каждым годом становится всё меньше:

Благочинный знал, что дело не в батюшке, которого прихожане любили, кажется, все крепче и крепче, а в том, что люди исчезали куда-то - умирали, уезжали, наверное, и численность жителей сокращалась [Шипов 2013: 212].

Одно из незадачливых духовных чад отца Сергия с несерьёзным именем Борька невесело говорит главе местной администрации о предстоящих похоронах останков воинов, найденных поисковиками: „Вот завтра захороним тридцать пять бойцов, и на этом братском кладбище народу станет больше, чем в нашем селе..." [Шипов 2013: 215].

Благочинного печалят невесёлые думы, как найти замену старенькому отцу Сергию, который в этом селе „четверть века бессменно: и храм разрушенный поднял, и матушку здесь похоронил. Дочка у него далеко где-то, не появляется, а он живет один-одинешенек - ничего не требует" [Шипов 2013: 212]. Подвижничество местного священника заключается не только в скромности быта, но и в духовной трезвости. Например, он отвечает отказом на предложение принять монашество и остаться в приходе, так как разумно оценивает свой возраст и силы:

...здесь у меня жизнь мужицкая: изба, огород, дрова, стирка... [...] Устану, правило монашеское отложу - вот и грех. А у меня их и так без счету [Шипов 2013: 213].

При чём же тут боковое зрение? Эти слова, разумеется, относятся не к батюшкам. Хотя как знать... Шипов умеет придавать своим названиям если не символический, то многомерно-знаковый смысл.

Весь сюжет рассказа сводится к череде нелепостей. Вечерняя прогулка Борьки с батюшками неожиданно для духовных лиц стала репетицией утиной охоты.

Он привел батюшек на берег озера и расставил метрах в десяти друг от друга у самой воды: - Позицию занимаем лицом к закату - так видимость сохраняется на час дольше. За спиной, глядите, темень тьмучая, а впереди - светло. В небо смотреть не надо - там бесконечность, и глаз не знает, на что настраиваться. Смотреть надо на воду перед собой [Шипов 2013: 213].

Юмор у Шипова очень часто строится на совмещении несовместимого. Борька совершенно серьёзно инструктирует духовных лиц, увлекаясь, впадая в специфические охотничьи подробности. Оба священника преклонных лет, да и охотиться им по сану не положено. Однако они послушно принимают требуемую позицию и почти не ропщут: 
- Шалопай ты, Борька, - вздохнул отец Сергий, виновато глянув на благочинного, - ну зачем ты нас сюда притащил?

Отец Александр успокаивающе махнул рукой:

- Ничего, постоим, закат красивый... [Шипов 2013: 214]

Охота без ружей и без уток свелась в итоге к невесёлому разговору со встретившейся начальницей Марьей Васильевной о предстоящих выборах и тревожной демографической ситуации. А в финале даже останки воинов не хоронят на местном кладбище, а перевозят далеко-далеко - туда, „где удалось найти взвод солдат для почетного караула и экскаватор. Или трактор с ковшом" (с. 215). Вся мелодика рассказа амбивалентна. На каждой странице есть смысловое и эмоциональное „покачивание” (термин Е.В. Капинос, применённый к малой прозе И.А. Бунина [Капинос 2014: 19]): от заботы к временному развлечению, от улыбки к горечи, от уток к покойникам. Шипов включает в свои рассказы эстетику абсурда, но никогда не довольствуется ей, как это часто бывает у постмодернистов. Абсурд нравственный и социальный пропущены им сквозь мощное поле раздумий о судьбе Родины и о промысле Божьем, определяющем эту судьбу. Эти размышления у Шипова оформлены скорее художественно, а не логически. И общую их концепцию можно уяснить на уровне цикла или книги, а не одного рассказа.

Реплики о боковом зрении дважды произносит не очень умный Борька, решивший просветить батюшек насчёт вечерней утиной охоты. „Боковое зрение засечет, если хоть какая-то точка будет перемещаться" [Шипов 2013: 214], - объясняет он священникам. И комментирует дальше, когда отец Сергий принял водомерок за уток: „Да-а... Обычное зрение у вас никуда не годится, а вот боковое - выручило: даже мелких насекомых в движении заметили" [Шипов 2013: 214].

Эти слова вроде бы ничего не проясняют, но в рамках всего цикла Долгота дней работают на некий подтекст. Доживающий свою нелёгкую жизнь в глухом селе отец Сергий не в состоянии остановить экономический и физический упадок, но может разделить судьбу с тем, кто не хочет или не может уехать из родного села. И его духовное зрение и „обычное”, и „боковое” - не подведёт. А вот на то, что творится в стране, действительно легче смотреть только боковым зрением. Но Шипов смотрит прямо, честно и с состраданием.

Труд пастырей в духовно и экономически неблагополучной России в случае русской глубинки и горче, и выше, и тяжелее, чем у их коллег в относительно благополучной Москве. Он формирует людей необыкновенно терпеливых, добрых, мужественных. Повторюсь: сам феномен праведности Шиповым не подчёркивается. По большей части он окру- 
жает своих „несвятых святых” густой сетью курьёзов, вроде бы ненужных частностей и - главное - авторским интонированием: неспешной улыбчивой повествовательностью, которая всегда выводит к каким-то открытиям. По такому принципу построены рассказы Отпуск, Чуркин-герой, Овсяное печенъе и многие другие.

В 2014 году о. Ярослав написал небольшой, в полстранички, рассказ о давней встрече со знаменитым поэтом (как всегда, неназванным). Написан он, вероятно, ради одного важного суждения, которое поэт высказывает любознательному школьнику:

Поэзия зарегулирована, она зажата рифмой и ритмом. А проза - свободна, в ней безграничный простор. Если стихотворение, даже самое гениальное, положить на музыку, выйдет всего лишь одна мелодия, ну, может, с некоторыми вариациями. А в прозе - столько мелодики, столько интонационного разнообразия. Вон Петр Ильич в «Пиковой даме» переложил на музыку несколько страниц пушкинской прозы - потрясающее богатство мелодий! Так что у прозы можно многому поучиться. Я, между прочим, так и делаю: учусь писать у русской прозы, честное слово [Шипов 2014: 44].

Прототип поэта - Давид Самойлов (1920-1990). На это есть прямое указание в финале рассказа, завершающегося так же, как маленькая поэма Самойлова Снегопад (1975):

Учусь писать у русской прозы,

Влюблён в её просторный слог,

Чтобы потом, как речь сквозь слёзы,

Я сам в стихи пробиться мог.

[Самойлов 1975]

Эта идея как нельзя лучше иллюстрирует специфику интонационной вариативности в рассказах Ярослава Шипова. Он тоже влюблён в „просторный слог” русской прозы и о подвижниках благочестия рассказывает, как правило, с сердечной теплотой, домашностью, не лишённой, впрочем, разнообразно интонированной эпической составляющей. Каждый рассказ не только по содержанию и месту действия, но и по звуку и мелодике отличается от соседнего. Музыкальное звучание его прозы влияет и на смысл, и на настроение. Для примера приведу финал Бокового зрения и начало следующего за ним рассказа (граница отделена названием):

Но хоронить им завтра никого не пришлось: останки воинов перевезли куда-то далеко-далеко, где удалось найти взвод солдат для почетного караула и экскаватор. Или трактор с ковшом. 


\section{Заказник}

Архиерей вызвал меня и отправил в командировку:

- Там художники, муж и жена, весьма преклонных годов - пожалуй, к восьмидесяти. Они передали нам несколько храмовых икон, и вообще много чего делают для Церкви [Шипов 2013: 215].

Траурно-печальный финал Бокового зрения вовсе не отменяется. Происходит интонационное переключение: новое событие вводится вместе с новым настроением и новым ритмом. Это важная составляющая и рассказов о праведниках, которые можно поставить рядом друг с другом (чего у Шипова в собранных лично им сборниках почти не случается), но мелодика рассказывания будет всякий раз иной: от весёлого к трагическому, от абсурдного к высокому, от сложной, развёрнутой фразы к незатейливым диалогам. Думается, составляя подборку рассказов, писатель всегда смотрит на стыки между ними, на смысловые и интонационные валентности, порождаемые их последовательностью.

И поэтому, повторюсь, общую идею его небольших рассказов стоит искать на уровне цикла или даже книги. По точному замечанию Елены Афониной, тексты в системе прозаического цикла,

оставаясь самостоятельными, ...становятся одновременно и эпизодами, фрагментами единого авторского высказывания. Каждый текст в цикле репрезентирует не завершённый художественный мир, а только часть его [Афонина 2005: 9].

Истории о праведниках обычно занимают сильные позиции начала и конца циклов. Но типы „несвятых святых” встречаются и внутри. Для автора они являются некими духовными маяками. Чем гуще тьма, тем ярче они сияют. Феномен святости в рассказах Шипова противостоит мотивам духовного и социального оскудения. Оба этих явления нерасторжимы в прозе о. Ярослава, ибо святость всегда стыдлива и внешне проявляет себя только при соприкосновении с противоположными началами: греха, малодушия, лицемерия и т.п.

Например, в остроумном, но горьком цикле Отказываться не впраbe о жизни священника в захолустном северном приходе несомненным нравственным светочем воспринимается Елизавета из одноимённого рассказа. Отчасти она напоминает солженицынскую Матрёну: её поведение противопоставлено всеобщему духовному одичанию. Но принципы раскрытия характера у Шипова совершенно другие. Да и темперамент Елизаветы иной, чем у солженицынской героини. Елизавета живёт в угасающем хуторе 1990-х, насчитывающем всего четыре двора и четырех жителей-родственников. Рассказчик, деревенский батюшка, бывший мо- 
сквич, образованный, прилежный в служении, сталкивается в своём приходе с разнообразными проявлениями невежества и духовной слепоты, с болью видит повсеместное пьянство и нежелание работать над собой. И поэтому островки нормы в деревенском социуме особенно дороги ему. Личность Елизаветы он считает „реликтовой”: „душа ее чудесным образом сохранила отсветы прежнего воспитания..." [Шипов 2013: 163].

В чём же это заключается? В жёсткой требовательности к себе, внутренней собранности, строгости. Раненная осколком при строительстве оборонительных сооружений ещё в семнадцатилетнем возрасте, она осталась инвалидом на всю жизнь. Но это слово ни разу не прозвучало в рассказе. С первых же характеристик Шипов вводит говорящую деталь, являющуюся комментарием не только к внешнему, но и внутреннему облику героини: „Елизавете было семьдесят лет, однако называть её бабкой было никак невозможно, и прежде всего потому, что она, в отличие от деревенских старух, прямо держала спину" [Шипов 2013: 163]. Несгибаемость спины и словно боярская стать идут не только от болезни, но и от ощущения правоты, которую несёт в себе эта крестьянка. Шипов не описывает быт Елизаветы, её борьбу за выживание. Скорее всего он был скудный. Авторское внимание привлекает духовная крепость героини и несомненный дар рассуждения, которым она щедро наделена:

С ней было легко разговаривать: она читала Иоанна Златоуста и хорошо понимала сущность духовных битв. Но утешительнее всего было слушать её рассуждения по всяким житейским поводам [Шипов 2013: 164].

В рассказе воспроизводятся два её разговора, случившиеся в разное время. Оба они касаются существенных сторон житейского поведения человека. В первом Елизавета осаживает матерящегося председателя колхоза:

- Не русское это дело... Когда человек молится, он верит, что каждое его слово услышат и поймут...

- Ну, - растерянно улыбается председатель.

- А если над нашей землей мат-перемат висит?.. Богородица позатыкает уши, а мы будем удивляться, что страна - в дерьме... [Шипов 2013: 164].

На возражения председателя о том, что всегда на Руси ругались и пили, Елизавета приводит опыт своей семьи. В коротком рассказе героини воспроизводится практика деревенского благочестия, известная нам лишь по церковным и семейным преданиям. Сквернословие, захлестнувшее страну, напрямую связывается Елизаветой с кочегарами революции: „Это все от кожаных курток пошло: от комиссаров да упол- 
номоченных разных - от нерусских..." [Шипов 2013: 164]. Елизавета интуитивно защищает духовное прошлое своей Отчизны от клеветы. Сквернословие для неё, так же как и „кожаные крутки” - чекисты и революционеры, явление глубоко нерусское по духу. Телесные немощи, трудная жизнь не исказили, а закалили её личность. И в этом тоже её отличие от солженицынской Матрёны. Та - ласковая долготерпеливица, шиповская Елизавета - духовная ратница.

Второй её разговор, на сей раз с вороватым церковным старостой, обнажает прямодушие и чувство юмора этой сильной женщины. „Большой в тебе подарок русскому Православию”, - говорит она „проворотливому" околоцерковному проходимцу. И аттестует его батюшке жёстко, без обиняков.

Рассказчик чутко вслушивается в её слова, жадно впитывая в себя „отсветы прежнего воспитания“. Когда безмерно удручает настоящее, повествователь ищет опоры в прошлом... Душа пастыря согревается от таких, например, воспоминаний:

Деда моего тоже в старосты долго уговаривали. Отказался. „Сейчас, - говорит, я в одном кармане в храм несу, а то, не приведи, Господи, в двух карманах из храма поволоку" [Шипов 2013: 167].

Такая Елизавета у батюшки на приходе - единственная. Как и Солженицын, Шипов завершает рассказ духовным наставлением. Но у Шипова он существенно приглушён по сравнению со знаменитым „не стоит село без праведника". Северный „хуторишко” почти уже „не стоит” всего четыре двора. Зато жила в нём молитвенница, пронёсшая веру через десятилетия атеистической пустыни. Финальный аккорд ставит не рассказчик, а староста, которого Елизавета только что отчитала. После отъезда из села он по-житейски нейтрально говорит батюшке: „А ее, между прочим, тоже как-то чудно прозывали... Негнущаяся, что ли?.. Или - несгибаемая?.. Во, точно: несгибаемая Елизавета" [Шипов 2013: 167].

И это звучит тоже сильно! В эпоху тотального малодушия шиповская Елизавета показывает пример волевого самостояния и председателю, и старосте, и нам, читателям. Можно сказать: несгибаемая! По меткому замечанию Ивана Леонова,

уникальность этих персонажей заключается в том, что в строго каноническом смысле они вовсе не могут быть названы святыми людьми. В отличие от древнерусского книжного канона, требующего идеализации главного героя, праведники у современных авторов изображаются не всегда однолинейно. Им могут быть свойственны противоречивые качества, они часто совершают поступки далекие 
от христианского идеала. Однако главным критерием, позволяющим отнести их к этой категории, становится глубокий покаянный настрой, признание собственных грехов, смирение, искренность, любовь к людям [Леонов 2011: 99].

Шиповская писательская манера исключает однообразие не только на уровне мелодики текста, но и на уровне типажей. Лица, место, время, обстоятельства непрестанно меняются. Меняются и акценты в изображении „несвятых святых”.

Например, в рассказе Дорожные съятиы описано путешествие батюшки-рассказчика вместе с неожиданно появившимся попутчиком - неким отцом Симеоном, бывшим инженером и прежде тайным, а ныне явным монахом. Кто он и откуда, выясняется постепенно и очень приблизительно:

Нам подсадили старика, который кем-то кому-то приходился, жил при каком-то южном монастыре, а теперь пустился в паломничество, желая лицезреть земли Северной Фиваиды [Шипов 2013: 221].

„Старчик” к тому же почти не ходит, глуховат, и кто и где его встретит, тоже неизвестно. Отец Симеон ведёт себя смирно, только всё время поёт молитвы - тем местным святым, чьи угодья пролетает машина: от радонежских святых к переславльским, от переславльских - к ростовским, а потом ярославским и так далее.

Весь рассказ переполнен провинциальными топонимами:

...а потом пошло - поехало: то знак „река Обнора” - и все Обнорские, то „река Нурома" - и Нуромские, а заодно Комельские, Спасо-Каменские, Сянжемские... На всякий дорожный указатель у отца Симеона тропари, кондаки, величания, молитвы, а иной раз и молебны [Шипов 2013: 223].

Рассказчик весело перечисляет мелькающие географические точки и имена святых, а о. Симеон резюмирует: „Потому что у нас, куда ни стань, везде свято место - земля такая" [Шипов 2013: 224]. Судя по географии, поездка продолжалась несколько часов. Столько же длилась радостная молитва старца, к которой неожиданно для себя присоединился и рассказчик. Немногословный водитель удивлённо комментирует: „Ну вы даёте!” [Шипов 2013: 223]. Потом за „старчиком” „примчался батюшка из соседней епархии" [Шипов 2013: 224] и забрал его в очередное путешествие. Вот, собственно, и весь рассказ.

Его интонация намеренно приближена к разговорной, но не равна ей. Разговорность отчётливо проступает в диалогах: короткие фразы, паузы, повторы. Например: 
Он только улыбается. Стало быть, еще и не слышит. Кричу:

- Как вас зовут?

- Отец Симеон... Да, отец Симеон... Семён, короче.

- Так вы монах?

- Монах, монах... Пострижен давно... еще тайно, тогда нельзя было, я ведь ин-

женером работал, это я теперь вот в подряснике... [Шипов 2013: 222].

Все остальные фрагменты текста „опеваются” плавным, мелодически выверенным голосом повествователя. По структуре предложения в тексте бывают и односоставные, и эллиптические, с одной или несколькими основами, с интонацией перечисления и без неё. Шипов интуитивно располагает их таким образом, что ритмический рисунок постоянно варьируется, уходит от инерции и автоматизма. Это видно и на уровне абзаца, и на уровне отдельного предложения. Например:

Недолго, однако, радовался я своему диковинному постояльцу: утром примчался батюшка из соседней епархии, забрал отца Симеона, и отправились они далее по святой земле страдающего Отечества [Шипов 2013: 224].

Обратим внимание на инверсию - обратный порядок главных членов в предложении (сначала сказуемое, потом подлежащее). Эта особенность немного сдвигает внимание читателя в сторону глаголов, т.е. действия. Весь рассказ посвящён путешествию, движению и молитве - тоже действию, только внутреннему.

Он, конечно же, повествует не столько о старце, сколько о России „убогой и обильной”, по слову Николая Некрасова. Есть у кого попросить защиты и помощи, есть к кому припасть, да мало кто это умеет. И если большинство читателей, да и сам рассказчик целиком ещё здесь, на земле, в страдающем Отечестве, то отец Симеон весь устремлён в Отечество небесное. Потому и радостно с ним рядом, и странно. Водитель сразу же после появления отца Симеона „сказал, что машина лёгкая и словно летит" [Шипов 2013: 222].

И в финале рассказа именно он, человек со стороны, подчёркивает то ли тайну, то ли чудо, пережитое рядом с таким обыкновенным старичком: „Все-таки мы тогда как-то странно ехали - машина летела, словно даже не касалась асфальта" [Шипов 2013: 224]. Шипов не пишет житие. Это, пожалуй, не его жанр, но никогда не проходит мимо святости. Чудо один из её показателей. И летящая по Руси машина - птица тройка XXI века - тоже какой-то знак - близости мира земного и небесного, неистребимости русского духовного пространства, просвечивающего через пространство физическое - часто неказистое и безрадостное. А объединяет его неприметный „старчик”, читающий дорожные святцы. Мы уже и забыли, что так называется рассказ. 
Любой исследователь Шипова неизбежно будет обращаться к поэтике названий. Интересны они и для нашей темы. Каждое заглавие у Шипова, как и положено, работает на общую идею рассказа или вступает с ней в конфликтные отношения. Показательно, что корень „свят” встречается в сборниках о. Ярослава крайне редко. В Дорожных святиах он, как нам кажется, очерчивает область незримой благодати, разлитой над „страдающим Отечеством”. Горький рассказ Святое дело из цикла Отказываться не вправе повествует о праздновании Троицы в отдалённой северной деревне, ежегодно превращающемся во всеобщую пьянку. Рассказ „повеселее” - Освящение (из цикла Долгота дней) - о „нехитром” деле освящения родильного отделения больницы, в том числе и абортария („Смотрю на милых докторш и начинаю осознавать, что каждая из них народу переколошматила больше, чем все наемные убийцы, взятые вместе..." [Шипов 2013: 315]), и целого этажа госбезопасности. То есть корень „свят" в шиповских названиях отражает разную степень духовного состояния героев - от полного его отсутствия („святым делом” оказывается пьянство на могилах) до всеприсутствия (святцами становится вся намоленная русская земля).

Но вот в рассказе Святой говорится о настоящем святом - архиепископе Луке Войно-Ясенецком, канонизированном в сонме новомучеников. Вернее об одном эпизоде из его подвижнической жизни - спасении юной девушки от смерти. И вновь история эта дана в обширном обрамлении - трескотне вечных паломниц по святым местам, которые уговорили свою молчаливую спутницу рассказать о чуде, пережитом ею в молодости. Неизвестный старый хирург, констатировавший: „Ей осталось жить двадцать минут”, - и названный рассказчицей „слепеньким старичком”, который „время терял” [Шипов 2013: 285], молился перед иконой Пресвятой Богородицы. Чудо происходит не только во время операции, но и до, и - спустя много лет - после неё. Рассказчица точно воспроизводит своё сумеречное предсмертное состояние:

И вдруг я - безбожница, комсомолка, выбросившая бабушкины иконы, взмолилась: „Пресвятая Богородица, спаси!” Я знаю, что говорить не могла, рот у меня пересох и губы не шевелились, я обращалась к Богородице мысленно, но старичок, подойдя ко мне, сказал: „Не тревожься - спасёт” ... [Шипов 2013: 285].

Простота и сверхъестественность в жизни святых идут рука об руку. В данном рассказе они противопоставлены суетности и многословию „церковных тётушек”, которые и скромную молчаливость их спутницы готовы истолковать превратно. Авторский голос заканчивает устный рассказ попутчицы: „Спустя годы узнала она, что оперировал её Сим- 
феропольский архиепископ Лука - великий хирург Войно-Ясенецкий... Святой... Такая история" [Шипов 2013: 285].

Чем не эпизод для жития? Ведь и житийная литература строится на церковном предании и устных рассказах. И всё-таки нет. Проза Шипова хоть и нацелена на поиск Божьего присутствия в мире, стилистически и проблемно целиком вписана в светскую, мирскую литературу. Вместо житийной канонической эпичности - авторское оценочное слово, вместо дидактики - юмор и целомудренное умолчание или осторожное прикосновение к предметам тонким и сложным. Как справедливо считает С.М. Червоненко или София,

отец Ярослав своими рассказами не подменяет житийной литературы, его включения образов святых в ткань художественных рассказов связаны с освещением духовных и нравственно-этических процессов нашего времени, их проекцией на большой фон живой вечности [Червоненко 2015: 142].

И даже реальная основа любого сюжета прикрыта у Шипова анонимностью, дающей больший простор читательским обобщениям. Например, рассказ Святой заканчивается кратким сообщением: „Впоследствии рассказчица стала монахиней одного из женских монастырей. А подружки её все снуют и снуют по приходам" [Шипов 2013: 285]. Линия судьбы, когда-то скорректированная живым подвижником, привела рьяную безбожницу к покаянию. Проза о. Ярослава вбирает в себя десятки таких нитей, сплетённых в тайный узор, разглядеть который можно только проанализировав ассоциативные смысловые пучки, порождаемые за счёт смены сюжетов, обстоятельств и мелодики высказывания. В случае обозначенной нами темы можно сказать так: редкие образы современных праведников в прозе Шипова создают необходимое автору поле надежды. И здесь важную организующую роль играет сам образ повествователя - чуткого, образованного верующего человека, не позволяющего унынию взять над собой верх. Он формирует у читателя ценностную иерархию, вершину которой занимает никогда не поминаемый Шиповым всуе Иисус Христос. Пёстрая мозаика характеров, забавных диалогов и страшных душевных уродств, жуткого нравственного запустения всё это охвачено умным, трезвым взглядом автора, любящего Россию в её величии и - ещё больше и мучительнее - в её унижении.

Святость шиповских подвижников скрыта за „долготой дней”, за шелухой реальности, за „мышьей беготнёй” жизни. Ведь чудотворная икона являет себя миру не сразу. Так и шиповские праведники спрятаны в житейских пустяках. В этом заключена и правда жизни (святой всегда уверен, что он первый грешник), и особый тип писательского мышления о. Ярослава, не выносящего открытого пафоса и стремящегося быть 
лишь предельно точным в передаче психологических типов людей и обстоятельств, в которых они себя проявляют.

В шиповской улыбчивости нет постмодернистской тотальной иронии и равнодушия. За юмором и пустяками всегда прячется любовь или горечь автора. Сюжеты о. Ярослава так или иначе зовут к размышлению о природе святости и работе над собой. А смешные словечки, курьёзы и - особенно - умолчания в его рассказах, весь заголовочный комплекс требуют особой интуитивной дешифровки, эмпатии, дружественности. Вот почему творчество Шипова интересно и простодушным церковным бабушкам, и интеллектуалам. Мы улыбаемся, но вместе с автором ищем, на чём стоять, кому верить, на что надеяться. Эти внутренние читательские посылы суггестивно заложены в прозе о. Ярослава. Духовное устроение праведников, устремлённое к небесам, содержит то прочное основание, которым и держится ещё наше „страдающее Отечество”. В этом уверен автор. В этом умеет он мягко и приветливо убедить и церковного, и нецерковного читателя.

\section{Библиография}

Афонина Е. Ю. 2005. Поэтика авторского прозаического изикла: автореферат диссертация на соискание ученой степени кандидата филологических наук, Тверь: Тверской государственный университет.

Гаспаров М. Л. 2003. Стиль, [в:] А. Н. Николюкин (ред.), Литературная энцииклопедия терминов и понятий, Москва: Интелвак.

Капинос Е. В. 2014. Поэзия Приморских Альп. Рассказы И. А. Бунина 1920-х годов, Москва: Языки славянской культуры.

Леонов И. С. 2011. Проблема типологии персонажей русской духовной прозы XXI b, „Русский язык за рубежом", № 5 (228).

Самойлов Д. 1975. Снегопад, электронный ресурс: https://afflatus.d3.ru/davidsamoilov-snegopad-1174417/?sorting=rating (доступ 9.09.2017).

Червоненко С. М. 2012. Повествование о смиренном человеке в современной прозе малых жанров (по рассказам священника Ярослава Шипова), „Вестник Московского государственного областного университета", № 5.

Червоненко С. М. 2015. Сюжеты с участием православных святых в земной жизни (по рассказам священника Ярослава Шипова), „Вестник новгородского государственного университета", № 84 .

Шевкунов Т. архим. 2011. Несвятые съятые, Москва: Олма Медиа Групп, Сретенский монастырь.

Шипов Я. 2013. Тоскующие по небесам, Сергиев Посад: СТСЛ.

Шипов Я. 2014. Нечто непоправимое, „Наш современник”, № 11. 
